\title{
Adherence to antiretroviral therapy in HIV-positive, male intravenous drug users in Pakistan
}

Bakht Ali ${ }^{1}$, Nighat Nisar ${ }^{2}$ and Faryal Nawab ${ }^{2}$

${ }^{1}$ School of Public Health, Dow University of Health Sciences, Karachi, Pakistan ${ }^{2}$ Deparment of Community Medicine, Dow University of Health

Sciences, Karachi, Pakistan (Correspondence to: Nighat Nisar: nisarnighat@hotmail.com)

\begin{abstract}
Background: Human immunodeficiency virus (HIV) is fifth leading cause of mortality and disability among infectious diseases worldwide. HIV burden is increasing annually and compliance with antiretroviral therapy (ART) is low among intravenous drug users, especially in developing countries.

Aim: To determine the adherence level to ART among HIV-positive intravenous drug users in Karachi Pakistan.

Methods: A cross-sectional study was conducted in 2015. A pretested questionnaire was administered to 375 of 3000 people who inject drugs, registered at the Civil Hospital in Karachi, Pakistan.

Results: The mean age was 30 years, 181 were married, 179 were illiterate and 287 had income $<5000$ rupees per month. Only 63 patients were adherent to ART and 343 were alcoholics. Nonadherence was greater in patients who were single and did not have children. The most common reason for missing ART was that they simply forgot to take the tablets.

Conclusion: We conclude that adherence to ART among intravenous drug users was low. Family cohesion and support were essential to maintain adherence to ART.

Keywords: HIV, ART adherence, IV drug users, Patient who use drugs (PWIDS), Nation AIDS Control Program

Citation: Bakht A; Nisar N; Nawab F. Adherence to antiretroviral therapy in HIV-positive, male intravenous drug users in Pakistan. East Mediterr Health J. 2018;24(3):237-242. https://doi.org/10.26719/2018.24.3.237

Received: 20/07/16; accepted: 01/03/17

Copyright ( C World Health Organization (WHO) 2018. Some rights reserved. This work is available under the CC BY-NC-SA 3.0 IGO license (https:// creativecommons.org/licenses/by-nc-sa/3.o/igo).
\end{abstract}

\section{Introduction}

People who inject drugs (PWIDs) are at high risk of human immunodeficiency virus (HIV) infection. It was estimated in 2016 that there were 11.7 million PWIDs worldwide, and $14 \%$ of them were infected with HIV (1). Approximately $78 \%$ of HIV-positive PWIDs were living in low- and middle-income countries. The burden of HIV among PWIDs is 3.4 million in Eastern Europe and Central Asia; 3.3 million in South Asia and Southeast Asia; and 2.3 million in East Asia and the Pacific Region (2). The overall global prevalence of HIV among PWIDs ranges between 20 and 40\% (3). Mortality among HIV-positive PWIDs is higher than among HIV patients who do not inject drugs (4).

In Pakistan, the prevalence of HIV was $<0.1 \%$ in 2001 and it had increased to $0.2 \%$ in 2012 (5). The number of patients registered with HIV infection was 130 000; of whom, 8900 were receiving antiretroviral therapy (ART) in 2016 (6). According to the Pakistan Global Aids Response Progress Report, prevalence of HIV among PWIDs increased from $10.8 \%$ in 2005 to $37.8 \%$ in 2011 (7).

HIV medication adherence is a vital component in viral suppression and decreasing the risk of developing drug resistance. It has been demonstrated that 95\% adherence is necessary to maintain viral suppression and halt disease progression (8). An international systematic review of several studies from 7 countries revealed that adherence levels were $33-97 \%$ (9). The cumulative adherence to ART was $70-89 \%$ among HIV patients who were receiving health services from Johns Hopkins AIDS Service Center (10). A study from India found that $73 \%$ and $77 \%$ of HIV patients were $>95 \%$ and $>90 \%$ adherent, respectively (11).

Active drug use has been associated with poor ART adherence. There are several factors, including sociodemographics, psychosocial factors, patients' experience during treatment, treatment-related issues (regimen, pill burden, dosing frequency, dietary instructions and adverse effects) and opioid substitution treatment $(12,13)$. A cohort study found that lack of stable relationships, depression, and drug injection were strong predictors of adherence failure (14).

Noncompliance with ART among HIV-positive patients is a major issue in Central Asia and Eastern Europe, and the situation is worst among HIV-positive PWIDs (15). Achievement of uniformity in prevention and treatment in PWIDs remains a challenge for healthcare systems and policy makers. The identification of predictors of adherence among PWIDs is crucial for healthcare providers and communities in Pakistan. There has been a lack of research on this important aspect of adherence to ART in HIV-positive patients, and especially among PWIDs in Pakistan. The objective of the present study was to determine the adherence level of ART among HIV-positive intravenous drug users in Karachi, Pakistan. 


\section{Methods}

A cross-sectional study was conducted from January to June 2015 at the ART Unit of the Civil Hospital, Karachi. Approximately 3000 HIV-positive PWIDs are currently enrolled at the unit and its outpatient clinic caters for $>50$ patients daily. About 375 HIV-positive patients aged $\geq 18$ years, who had injected drugs at least once in the previous 12 months, were included in the study through purposive sampling after obtaining informed consent. Patients who had multiorgan failure or other complications were excluded. The sample size of 375 was calculated using the World Health Organization (WHO) Calculator software; the frequency of ART adherence was taken as $40 \%$ with $95 \%$ confidence interval and $5 \%$ margin of error. The study was approved by the Research Committee of Dow University of Health Sciences, Karachi, Pakistan, and written permission was obtained from the Sind AIDS Control Program Director. Full confidentiality and privacy were maintained throughout the study.

Information regarding sociodemographics, psychosocial factors and adherence to treatment was obtained using a pretested questionnaire that was adapted from AIDS Control Trial Group (ACTG) Adherence Baseline Questionnaire (16). Adherence to ART was a dependent variable, while sociodemographics and psychosocial factors such as age, marital status, education, monthly income, alcohol dependency and history of unsafe sex practices were independent variables. Patients who missed $\leq 3$ doses during the previous month were considered to be the $>95 \%$ adherence group (adherent group). However, those who missed $>3$ doses were considered to be the $<95 \%$ adherence group (nonadherent group).

Data were entered and analysed using SPSS version 21.0. Mean and standard deviation (SD) were calculated

\begin{tabular}{lll}
\hline $\begin{array}{l}\text { Table } 1 \text { Distribution of sociodemographic characteristics among } \\
\text { HIV-positive PWIDs (n = 375) }\end{array}$ & Frequency & Percentage \\
$\begin{array}{l}\text { Sociodemographic } \\
\text { characteristics }\end{array}$ & \\
\hline Age (yr) & 192 & \\
18-30 & 112 & 51.2 \\
31-40 & 71 & 29.8 \\
> 40 & & 19 \\
Marital status & 175 & \\
Single & 181 & 46.7 \\
Married & 19 & 48.3 \\
Divorced & & 5.1 \\
\hline Educational attainment & 179 & \\
Illiterate & 113 & 47.7 \\
5 yr & 64 & 30.1 \\
10 yr & 19 & 17.1 \\
> 10 yr & & 5.1 \\
\hline Monthly income (rupees) & 287 & \\
< 5000 & 69 & 76.5 \\
5000-10 ooo & 18 & 4.8 \\
11 000-15 000 & 1 & 0.2 \\
> 15 000 & & \\
\hline
\end{tabular}

HIV = human immunodeficiency virus; PWIDs = people who inject drugs. for the quantitative data. Frequencies and percentages were calculated for categorical data. Univariate analysis was performed to determine the association between dependent and independent variables, and variables with $\mathrm{P}<0.10$ were further analysed by multiple logistic regression model. In multiple logistic regression analysis, variables with $\mathrm{P}<0.05$ were considered significant.

\section{Results}

\section{Sociodemographic characteristics}

Mean age of the respondents was 30.32 (SD, 9.59) years (Table 1). Most of the participants were aged 18-30 years $(192,51.2 \%)$ and had a monthly income $<5000$ Pakistani rupees $(287,76.5 \%)$.

\section{Adherence to ART among HIV-positive patients}

Seventy (18.7\%) participants missed up to 3 doses during the past month and were classified as the adherent group, and 305 (81.3\%) participants missed $>3$ doses of ART during the last month and were classified as the nonadherent group.

\section{Reasons for missing ART}

Three hundred and sixty (96\%) respondents reported that they simply forgot to take their medication; 338 (90.2\%) missed ART due to lack of family support; 145 (38.6\%) missed ART to avoid the adverse effects; and 58 (15.5\%) missed ART for other reasons, including feeling that they had too many pills, and feeling sick after taking ART. All patients reported that they never ran out of pills.

\section{Factors associated with adherence to ART}

Seventy patients were adherent to ART: 51 (72.9\%) were aged > 40 years; 47 (67.1\%) were married; 51 (72.9\%) had monthly income < 5000 rupees; 49 (5.7\%) reported having intercourse with an HIV-positive man in the past month; $6(8.6 \%)$ reported having intercourse with an HIV-positive women in the past month; and 11 (15.7\%) had full family support for treatment and medication (Table 2). In univariate analysis HIV patients who were aged $>40$ years, were married, had children and had full family support in taking ART had higher odds of being adherent to ART compared to those who were single, were aged < 40 years, did not have children and did not have complete family support. In multiple logistic regression patients who forgot to take ART > 3 times during the last month were significantly nonadherent to ART while age, marital status, education, income, number of children and family support did not show significant association with adherence to ART.

\section{Discussion}

We found low adherence to ART among HIV patients who were injectable drug users. Seventy (18.7\%) of the study participants had missed ART $>3$ times during the previous month. Most of the patients simply forgot to take ART.

In this study, adherence to ART was alarmingly low. Similar results have been reported in studies from 


\begin{tabular}{|c|c|c|c|c|c|c|c|}
\hline \multirow[t]{2}{*}{ Variables } & \multirow{2}{*}{$\begin{array}{c}\text { Frequency } \\
\mathbf{n}=375\end{array}$} & \multirow{2}{*}{$\begin{array}{c}\text { Adherent } \\
\mathbf{n}=\mathbf{7 0}\end{array}$} & \multirow{2}{*}{$\begin{array}{c}\text { Nonadherent } \\
\mathbf{n}=305\end{array}$} & \multicolumn{2}{|c|}{ Univariate analysis } & \multicolumn{2}{|c|}{ Multiple logistic regression } \\
\hline & & & & $\begin{array}{c}\text { COR } \\
(95 \% \mathrm{CI})\end{array}$ & $\mathbf{P}$ & $\begin{array}{c}\text { AOR } \\
(95 \% \mathrm{CI})\end{array}$ & $\mathbf{P}$ \\
\hline \multicolumn{8}{|l|}{ Age $(y r)$} \\
\hline $\begin{array}{l}>40 \\
<40\end{array}$ & $\begin{array}{l}71(18.9 \%) \\
304(81.1 \%)\end{array}$ & $\begin{array}{l}19(27.1 \%) \\
51(72.9 \%)\end{array}$ & $\begin{array}{l}52(17 \%) \\
253(83 \%)\end{array}$ & $\begin{array}{l}1.813(0.989-3.321) \\
\text { Ref }\end{array}$ & 0.054 & $1.606(0.849-3.037)$ & 0.967 \\
\hline \multicolumn{8}{|c|}{ Marital status } \\
\hline $\begin{array}{l}\text { Single } \\
\text { Married }\end{array}$ & $\begin{array}{l}175(46.6 \%) \\
200(53.4 \%)\end{array}$ & $\begin{array}{l}23(32.9 \%) \\
47(67.1 \%)\end{array}$ & $\begin{array}{l}152(49.8 \%) \\
153(50.2 \%)\end{array}$ & $\begin{array}{l}2.030(1.175-3.508) \\
\text { Ref }\end{array}$ & 0.010 & $1.862(0.829-4.181)$ & 0.145 \\
\hline \multicolumn{8}{|c|}{ Educational attainment (yr) } \\
\hline $\begin{array}{l}<5 \\
>5\end{array}$ & $\begin{array}{l}292(77.9 \%) \\
83(22.1 \%)\end{array}$ & $\begin{array}{l}53(75.7 \%) \\
17(24.3 \%)\end{array}$ & $\begin{array}{l}239(78.3 \%) \\
66(17.7 \%)\end{array}$ & $\begin{array}{l}1.162(0.631-2.139) \\
\text { Ref }\end{array}$ & 0.631 & - & \\
\hline \multicolumn{8}{|c|}{ Total monthly income in Pakistani rupees } \\
\hline $\begin{array}{l}<5000 \\
>5000\end{array}$ & $\begin{array}{l}287(76.5 \%) \\
88(23.5 \%)\end{array}$ & $\begin{array}{l}51(72.9 \%) \\
19(27.1 \%)\end{array}$ & $\begin{array}{l}236(77.4 \%) \\
69(22.6 \%)\end{array}$ & $\begin{array}{l}1.274(0.706-2.301) \\
\operatorname{Ref}\end{array}$ & 0.421 & - & \\
\hline \multicolumn{8}{|c|}{ Have children } \\
\hline $\begin{array}{l}\text { Yes } \\
\text { No }\end{array}$ & $\begin{array}{l}182(48.5 \%) \\
193(51.4 \%)\end{array}$ & $\begin{array}{l}29(41.4 \%) \\
41(58.6 \%)\end{array}$ & $\begin{array}{l}164(53.8 \%) \\
141(46.2 \%)\end{array}$ & $\begin{array}{l}1.644(0.972-2.783) \\
\operatorname{Ref}\end{array}$ & 0.064 & $1.862(0.829-4.18)$ & 0.132 \\
\hline \multicolumn{8}{|c|}{ Family supports treatment } \\
\hline $\begin{array}{l}\text { Yes } \\
\text { No }\end{array}$ & $\begin{array}{l}37(9.8 \%) \\
338(90.2 \%)\end{array}$ & $\begin{array}{l}11(15.7 \%) \\
59(84.3 \%)\end{array}$ & $\begin{array}{l}26(8.5 \%) \\
279(91.5 \%)\end{array}$ & $\begin{array}{l}2.001(0.937-4.273) \\
\operatorname{Ref}\end{array}$ & 0.069 & $1.486(0.633-3.487)$ & 0.363 \\
\hline \multicolumn{8}{|c|}{ Had intercourse with HIV-positive man during last month } \\
\hline $\begin{array}{l}\text { Yes } \\
\text { No }\end{array}$ & $\begin{array}{l}16(4.3 \%) \\
359(95.7 \%)\end{array}$ & $\begin{array}{l}49(5.7 \%) \\
66(94.3 \%)\end{array}$ & $\begin{array}{l}12(3.9 \%) \\
293(96.1 \%)\end{array}$ & $\begin{array}{l}0.676(0.211-2.161) \\
\text { Ref }\end{array}$ & 0.506 & - & \\
\hline \multicolumn{8}{|c|}{ Had intercourse with HIV-positive woman during last month } \\
\hline $\begin{array}{l}\text { Yes } \\
\text { No }\end{array}$ & $\begin{array}{l}30(8.5 \%) \\
343(91.5 \%)\end{array}$ & $\begin{array}{l}6(8.6 \%) \\
64(91.4 \%)\end{array}$ & $\begin{array}{l}279(92.1 \%) \\
24(7.9 \%)\end{array}$ & $\begin{array}{l}0.918(0.360-2.337) \\
\text { Ref }\end{array}$ & 0.851 & - & \\
\hline \multicolumn{8}{|c|}{ Forgot to take medication during last month $>3$ times } \\
\hline $\begin{array}{l}\text { Yes } \\
\text { No }\end{array}$ & $\begin{array}{l}360(96 \%) \\
15(4 \%)\end{array}$ & $\begin{array}{l}63(90 \%) \\
7(10 \%)\end{array}$ & $\begin{array}{l}297(93.4 \%) \\
8(2.6 \%)\end{array}$ & $\begin{array}{l}4.125(1.443-11.79) \\
\text { Ref }\end{array}$ & 0.005 & $3.46(1.086-11.04)$ & 0.036 \\
\hline
\end{tabular}

$\mathrm{AOR}=$ adjusted odds ratio; $\mathrm{ART}=$ antiretroviral therapy; $\mathrm{CI}=$ confidence interval $\mathrm{COR}=$ crude odds ratio; $\mathrm{HIV}=$ human immunodeficiency virus; Ref = reference value .

Rwanda (17) and Hanoi (18) in which adherence to ART was significantly lower among PWIDs. This low level of adherence is lower than that in other developing countries such as India (19) and Thailand (20). A study conducted in California reported that $11 \%$ of the patients missed 1 dose of ART prior to the day of interview, and the most common reason for missing ART was that they simply forgot (21), which is consistent with the finding of our study. Studies from Canada and United States of America (USA) reported that PWIDs who were on opioid substitution showed improved adherence to ART (22, 23). The low adherence in our study can be attributed to poor utilization of healthcare facilities or lack of new strategies such as opioid substitution therapy or directly assisted ART.

Our univariate model showed that HIV-positive PWIDs who were married and had children were more likely to be adherent to ART. However, these factors remained insignificant in our multivariate model. A previous review has shown that adequate support services for PWIDs are the most important factor in ART adherence (24). A previous meta-analysis has indicated that social support and family coherence are important for healthcare utilization and conduciveness and adherence to ART among HIV patients (25). These findings highlight the importance of family support in treatment and adherence to ART. HIV patients who are living with their families receive better moral, emotional and financial support, which helps them to be more adherent to ART. It is noteworthy that family relationships are a strong predictor for better adherence to ART, hence family involvement is needed throughout the medication process. Low levels of family support can be attributed to stigmatization of HIV and PWIDs in our society.

A study conducted in Taiwan reported that PWIDs who were illiterate and of low socioeconomic status were less adherent to ART (26). In contrast, we did not report a significant association of education and income with adherence to ART, which could be because most of the patients were illiterate and had low income. Similar findings have been reported from other studies conducted in Columbia and India $(27,28)$. Education has a positive impact on ART adherence by facilitating communication with healthcare providers. Low literacy rate is a major obstacle to taking ART correctly. Another study conducted in Nepal reported that literate patients 
were more adherent to ART compared to illiterate patients, which shows that education plays a significant role in adherence to ART (29). It was further observed that knowledge, expectation and belief of participants regarding ART depend on health education and awareness. Another study from India did not find any significant association between literacy and adherence to ART, and it was reported that psychosocial factors influence adherence to ART (30).

We found that most of the respondents missed ART during last month and the most common reason was that they simply forgot to take their medication, and no patients ran out of pills. In contrast, in a study from Mississippi, USA, in which most of the patients missed ART over the last 3 days, the major reason was running out of pills (31). Another study conducted in Uganda showed that similar numbers of participants forgot to take their medication, ran out of pills and felt sick after taking medication (32). Another study from Uganda suggested that willingness for treatment and compliance were major factors affecting adherence to ART (33). In contrast to our findings, a study from Tanzania showed that major barriers to adherence were the religious festivals of Ramadan among Muslims and Teej among Hindus, and fasting made it difficult to take ART (34).

There were several limitations to our study. First, this was a cross-sectional study, so a temporal association between the independent variables and outcome could not be established. Second, we relied on self-reports for adherence so the results may have been subject to reporting bias.

In conclusion, this study showed that adherence to ART among HIV-positive PWIDs was alarmingly low. Forgetting to take medication was the most common reason for nonadherence to ART. Measures should be taken to provide social support and acceptance of HIVpositive PWIDs in their families and society to make ART programmes successful. Further interventional studies are recommended to integrate opioid substitution therapy and directly observed therapy for PWIDs, which may improve adherence to ART. It is further recommended that an e-reminder network system can be developed that could help patients to remember their medication timing.

Funding: None.

Competing interests: None declared.

\section{Observance du traitement antirétroviral chez les consommateurs de drogue par voie intraveineuse séropositifs au VIH au Pakistan}

\section{Résumé}

Contexte : L'infection par le virus de l'immunodéficience humaine (VIH) est la cinquième cause principale de mortalité et d'incapacité dues à des maladies infectieuses dans le monde entier. La charge de VIH augmente chaque année et l'observance du traitement antirétroviral (TAR) est faible chez les consommateurs de drogues par voie intraveineuse, en particulier dans les pays en développement.

Objectif: Déterminer le niveau d'observance du TAR chez les consommateurs de drogue par voie intraveineuse séropositifs au VIH à Karachi (Pakistan)

Méthodes : Une étude transversale a été conduite en 2015. Un questionnaire préalablement testé a été administré à 375 des 3000 consommateurs de drogues par injection enregistrés au Civil Hospital de Karachi (Pakistan).

Résultats : L'âge moyen était 30 ans, 181 étaient mariés, 179 étaient analphabètes et 287 avaient des revenus inférieurs à 5000 roupies par mois. Seuls 63 patients observaient leur traitement antirétroviral et 343 étaient alcooliques. La nonobservance était supérieure chez les patients célibataires et sans enfants. La raison la plus courante justifiant le fait de ne pas prendre le TAR était tout simplement l'oubli de la prise des comprimés.

Conclusion : Nous concluons que l'observance du TAR chez les consommateurs de drogues par voie intraveineuse est faible. La cohésion familiale et le soutien des proches sont essentiels pour maintenir l'observance du TAR.

$$
\begin{aligned}
& \text { الالتزام بالعلاج المضاد للفيروسات القهقرية في صفوف الذكور المصابين بفيروس العوز المناعي البشري المتعاطين }
\end{aligned}
$$

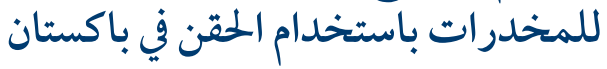

$$
\begin{aligned}
& \text { بخت علي، نغهت نثار، فريال نواب } \\
& \text { الخلاصة }
\end{aligned}
$$

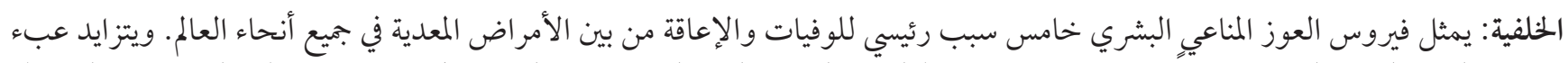

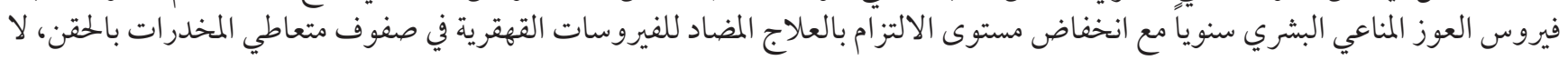
سييا في البلدان النامية.

الهدف: تحديد مستوى الالتزام بالعلاج المضاد للفيروسات القهقرية في صفوف متعاطي المخدرات بالحقن المصابين بفيروس العوز المناعي البشري في كراتشي بباكستان. 


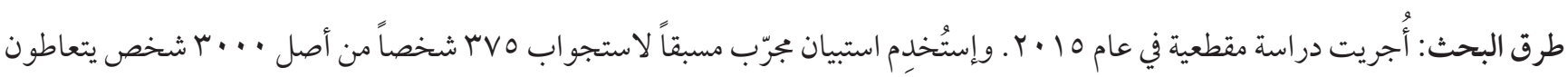

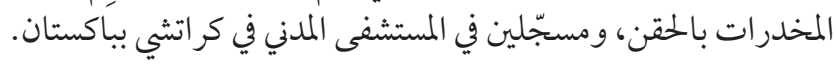

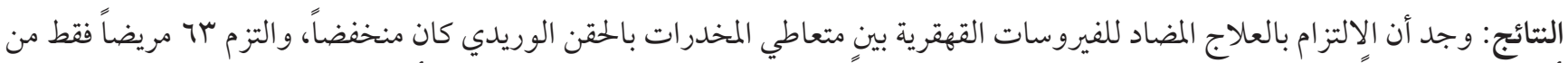

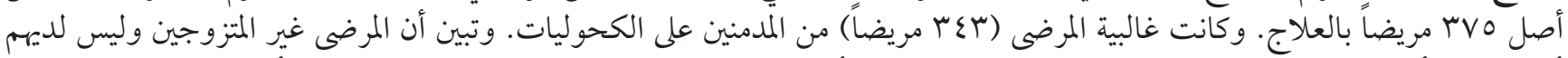

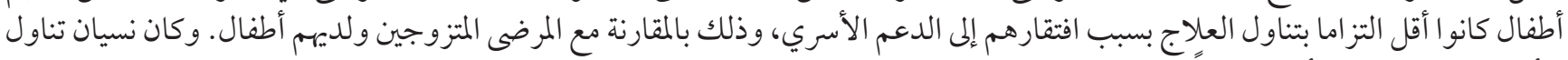

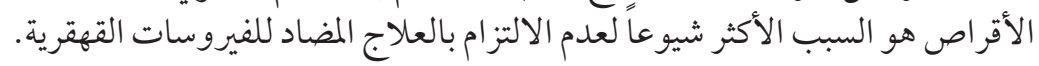

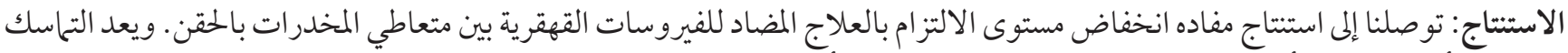

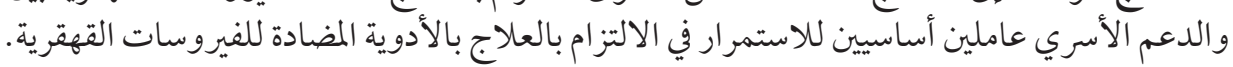

\section{References}

1. Harm Reduction International. Global state of harm reduction; 2016 (http://www.hri.global, accessed 15 November 2017).

2. Preventing HIV among drug users. Global AIDS update 2016 (http://www.unaids.org/en/targetsandcommitments/preventinghivamongdrugusers, accessed September 2016

3. Glass TR, De Geest S, Weber R, Vernazza PL, Rickenbach M, Furrer H, et al. Correlates of self-reported nonadherence to antiretroviral therapy in HIV-infected patients: the Swiss HIV Cohort Study. J Acquir Immune Defic Syndr. 2006 Mar;41(3):385-92. PMID:16540942

4. Spiller MW, Broz D, Wejnert C, Nerlander L, Paz-Bailey G; Centers for Disease Control and Prevention. HIV infection and HIV associated behaviors among persons who inject drugs - 20 cities, United States, 2012. MMWR Morb Mortal Wkly Rep. 2015 Mar 20;64(10):270-5. PMID:25789742

5. Bergenstrom A, Achakzai B, Furqan S. ulHaq M, Khan R, Saba M. Drug-related HIV epidemic in Pakistan: a review of current situation and response and the way forward beyond 2015. Harm Reduct J. 2015;12(1):1. PMCID:PMC4608141

6. HIV and AIDS Estimates. Country fact sheet Pakistan 2016 (http://www.unaids.org/en/regionscountries/countries/pakistan, accessed 15 November 2017).

7. Pakistan Global AIDS Response Progress Report (GARPR) 2015. Country Progress Report Pakistan. Islamabad: National AIDS Control Program; 2015 (http://www.unaids.org/sites/default/files/country/documents/PAK_narrative_report_2015.pdf, accessed 30 October 2017).

8. Kim SH, Gerver SM, Fidler S, Ward H. Adherence to antiretroviral therapy in adolescents living with HIV: systematic review and meta-analysis. AIDS. 2014 Aug 24;28(13):1945-56. PMID:24845154

9. Feelemyer J, Des Jarlais D, Arasteh K, Uusküla A. Adherence to antiretroviral medications among persons who inject drugs in transitional, low and middle income countries: an international systematic review. AIDS Behav. 2015 Apr;19(4):575-83. PMID:25331268

10. Murphy DA, Belzer M, Durako SJ, Sarr M, Wilson CM, Muenz LR. Longitudinal antiretroviral adherence among adolescents infected with human immunodeficiency virus. Arch Pediatr Adolesc Med. 2005 Aug;159(8):764-70. PMID:16061785

11. Pahari S, Roy S, Mandal A, Kuila S, Panda S. Adherence to anti-retroviral therapy \& factors associated with it: a community based cross-sectional study from West Bengal, India. Indian J Med Res. 2015 Sep;142(3):301-10. PMID:26458346

12. Dutta A, Wirtz AL, Baral S, Beyrer C, Cleghorn FR. Key harm reduction interventions and their impact on the reduction of risky behavior and HIV incidence among people who inject drugs in low-income and middle-income countries. Curr Opin HIV AIDS. 2012 Jul;7(4):362-8. PMID:22647588

13. Protopopescu C, Raffi F, Roux P, Reynes J, Dellamonica P, Spire B, et al. Factors associated with non-adherence to long-term highly active antiretroviral therapy: a 10 year follow-up analysis with correction for the bias induced by missing data. J Antimicrob Chemother. 2009 Sep;64(3):599-606. PMID:19602563

14. Malta M, Magnanini MM, Strathdee SA, Bastos FI. Adherence to antiretroviral therapy among HIV-infected drug users: a meta-analysis. AIDS Behav. 2010 Aug;14(4):731-47. PMID:19020970

15. Jolley E, Rhodes T, Platt L, Hope V, Latypov A, Donoghoe M, et al. HIV among people who inject drugs in Central and Eastern Europe and Central Asia: a systematic review with implications for policy. BMJ Open. 2012 Oct 18;2(5):e001465. PMID:23087014

16. AIDS Clinical Trial Group (ACTG). Adherence baseline questionnaire. (http://caps.ucsf.edu/uploads/tools/surveys/pdf/2098.4186. pdf, accessed 30 October 2017).

17. Au JT, Kayitenkore K, Shutes E, Karita E, Peters PJ, Tichacek A, et al. Access to adequate nutrition is a major potential obstacle to antiretroviral adherence among HIV-infected individuals in Rwanda. AIDS. 2006 Oct 24;20(16):2116-8. PMID:17053359

18. Izenberg JM, Bachireddy C, Soule M, Kiriazova T, Dvoryak S, Altice FL. High rates of police detention among recently released HIV-infected prisoners in Ukraine: implications for health outcomes. Drug Alcohol Depend. 2013 Nov 1;133(1):154-60. PMID:23769160

19. Mhaskar R, Alandikar V, Emmanuel P, Djulbegovic B, Patel S, Patel A, et al. Adherence to antiretroviral therapy in India: a systematic review and meta-analysis. Indian J Community Med. 2013 Apr;38(2):74-82. PMID:23878418 
20. Li L, Lee S-J, Wen Y, Lin C, Wan D, Jiraphongsa C. Antiretroviral therapy adherence among patients living with HIV/AIDS in Thailand. Nurs Health Sci. 2010 Jun;12(2):212-20. PMID:20602694

21. Chesney MA, Ickovics JR, Chambers DB, Gifford AL, Neidig J, Zwickl B, et al. Self-reported adherence to antiretroviral medications among participants in HIV clinical trials: the AACTG adherence instruments. AIDS Care. 2000 Jun;12(3):255-66. PMID:10928201

22. Günthard HF, Aberg JA, Eron JJ, Hoy JF, Telenti A, Benson CA, et al. Antiretroviral treatment of adult HIV infection: 2014 recommendations of the International Antiviral Society-USA Panel. JAMA. 2014 Jul 23-30;312(4):410-25. PMID:25038359

23. Joseph B, Wood E, Hayashi K, Kerr T, Barrios R, Parashar S, et al. Factors associated with initiation of antiretroviral therapy among HIV-positive people who use injection drugs in a Canadian setting. AIDS. 2016 Mar 27;30(6):925-32. PMID:26636927

24. Wasti SP, van Teijlingen E, Simkhada P, Randall J, Baxter S, Kirkpatrick P, et al. Factors influencing adherence to antiretroviral treatment in Asian developing countries: a systematic review. Trop Med Int Health. 2012 Jan;17(1):71-81. PMID:21967241

25. Roux P, Kouanfack C, Cohen J, Marcellin F, Boyer S, Delaporte E, et al. Adherence to antiretroviral treatment in HIV-positive patients in the Cameroon context: promoting the use of medication reminder methods. J Acquir Immune Defic Syndr. 2011 Jul 1;57(1) Suppl 1:S40-3. PMID:21857285

26. Yen Y-F, Yen M-Y, Lin T, Li L-H, Jiang X-R, Chou P, et al. Prevalence and factors associated with HIV infection among injection drug users at methadone clinics in Taipei, Taiwan. BMC Public Health. 2014 Jul 4;14:682-5. PMID:24996558

27. Gonzalez A, Mimiaga MJ, Israel J, Andres Bedoya C, Safren SA. Substance use predictors of poor medication adherence: the role of substance use coping among HIV-infected patients in opioid dependence treatment. AIDS Behav. 2013 Jan;17(1):168-73. PMID:23008124

28. Cohn SE, Jiang H, McCutchan JA, Koletar SL, Murphy RL, Robertson KR, et al. Association of ongoing drug and alcohol use with non-adherence to antiretroviral therapy and higher risk of AIDS and death: results from ACTG 362. AIDS Care. 2011 Jun;23(6):775-85. PMID:21293986

29. Shah B, Walshe L, Saple DG, Mehta SH, Ramnani JP, Kharkar RD, et al. Adherence to antiretroviral therapy and virologic suppression among HIV-infected persons receiving care in private clinics in Mumbai, India. Clin Infect Dis. 2007 May 1;44(9):1235-44. PMID:17407045

30. Anuradha S, Joshi A, Negi M, Nischal N, Rajeshwari K, Dewan R. Factors influencing adherence to ART: new insights from a center providing free ART under the national program in Delhi, India. J Int Assoc Provid AIDS Care. 2013 May-Jun;12(3):195-201. PMID:22247335

31. Amico KR, Konkle-Parker DJ, Cornman DH, Barta WD, Ferrer R, Norton WE, et al. Reasons for ART non-adherence in the Deep South: adherence needs of a sample of HIV-positive patients in Mississippi. AIDS Care. 2007 Nov;19(10):1210-8. PMID:18071964

32. Shumba C, Atuhaire L, Imakit R, Atukunda R, Memiah P. Missed doses and missed appointments: adherence to ART among adult patients in Uganda. ISRN AIDS. 2013 Jan 14;2013:270914. PMID:24052886

33. Kamarulzaman A, Altice FL. Challenges in managing HIV in people who use drugs. Curr Opin Infect Dis. 2015 Feb;28(1):10-6. PMID:25490106

34. Tomori C, Kennedy CE, Brahmbhatt H, Wagman JA, Mbwambo JK, Likindikoki S, et al. Barriers and facilitators of retention in HIV care and treatment services in Iringa, Tanzania: the importance of socioeconomic and sociocultural factors. AIDS Care. 2014;26(7):907-13. PMID:24279762 